\title{
Unique among ciliopathies: primary ciliary dyskinesia, a motile cilia disorder
}

\author{
Kavita Praveen, Erica E. Davis, and Nicholas Katsanis*
}

Address: Center for Human Disease Modeling, Duke University Medical Center, Durham, NC 27701, USA

*Corresponding author: Nicholas Katsanis (katsanis@cellbio.duke.edu)

Fl000Prime Reports 2015, 7:36 (doi:10.12703/P7-36)

All FI000Prime Reports articles are distributed under the terms of the Creative Commons Attribution-Non Commercial License (http://creativecommons.org/licenses/by-nc/3.0/legalcode), which permits non-commercial use, distribution, and reproduction in any medium, provided the original work is properly cited.

The electronic version of this article is the complete one and can be found at: http://f $1000 . c o m / p r i m e /$ reports/b/7/36

\begin{abstract}
Primary ciliary dyskinesia (PCD) is a ciliopathy, but represents the sole entity from this class of disorders that results from the dysfunction of motile cilia. Characterized by respiratory problems appearing in childhood, infertility, and situs defects in $\sim 50 \%$ of individuals, PCD has an estimated prevalence of approximately I in 10,000 live births. The diagnosis of PCD can be prolonged due to a lack of disease awareness, coupled with the fact that symptoms can be confused with other more common genetic disorders, such as cystic fibrosis, or environmental insults that result in frequent respiratory infections. A primarily autosomal recessive disorder, PCD is genetically heterogeneous with $>30$ causal genes identified, posing significant challenges to genetic diagnosis. Here, we provide an overview of PCD as a disorder underscored by impaired ciliary motility; we discuss the recent advances towards uncovering the genetic basis of PCD; we discuss the molecular knowledge gained from PCD gene discovery, which has improved our understanding of motile ciliary assembly; and we speculate on how accelerated diagnosis, together with detailed phenotypic data, will shape the genetic and functional architecture of this disorder.
\end{abstract}

\section{Introduction}

The cilium is a microtubule-rich organelle that protrudes from the apical membrane of most vertebrate cells (Figure 1). Observed initially via a light microscope over 300 years ago [1], and largely thought of as "vestigial" or "rudimentary" organelles, cilia garnered attention in 1976 because of their association with PCD (also known as Kartagener syndrome when associated with situs inversus) by Bjorn Afzelius [2]. He described four patients with chronic sinusitis, bronchitis, frequent ear infections and immotile sperm, three of whom displayed situs inversus totalis (reversal in placement of body organs). He observed a lack of ciliary motion in biopsy samples from bronchial mucosa of one patient, along with an absence of the normal numbers of dynein arms in ciliary electron micrographs [2]. The seemingly stationary cilia in these patients led to the initial naming of the disease as "immotile-cilia syndrome" [3]. Further investigation into the disorder, however, showed the cilia to have dysfunctional motility, rather than a lack of all movement; thus the clinical disorder was renamed primary ciliary dyskinesia [4].

Cilia can be found on cells within almost all organ systems in the body (Figure 1A, B, C). Historically, cilia have been divided into two types based on their ability to move: motile cilia and primary (non-motile) cilia (Figure 1D). While motile cilia achieved prominence through their connection to PCD, and their functions in cell movement (e.g. sperm) and flow generation (e.g. mucosa), the importance of primary cilia remained underappreciated for several years after their discovery. The first evidence of an important sensory function for primary cilia came from the discovery that the mutation underscoring the cystic renal phenotype of the $\operatorname{Tg} 737$ mouse mutant was a hypomorphic allele in the gene encoding IFT88, a protein important for the assembly of flagella in Chlamydomonas [5]. Subsequently, it was 
Figure I. Overview of ciliary ultrastructure and comparison between motile and non-motile cilia

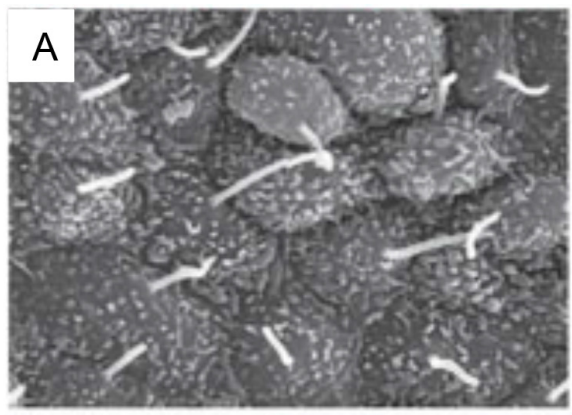

D

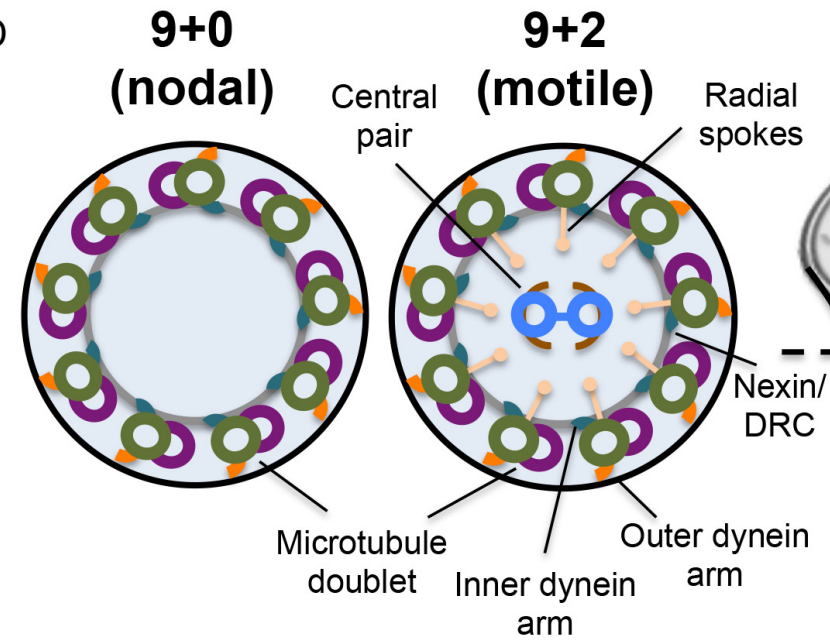

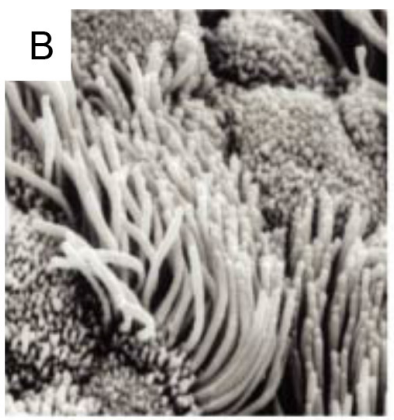

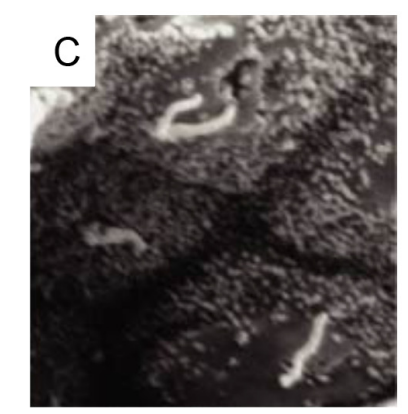

\section{$9+0$} (non-motile)

\section{Basal \\ Body}
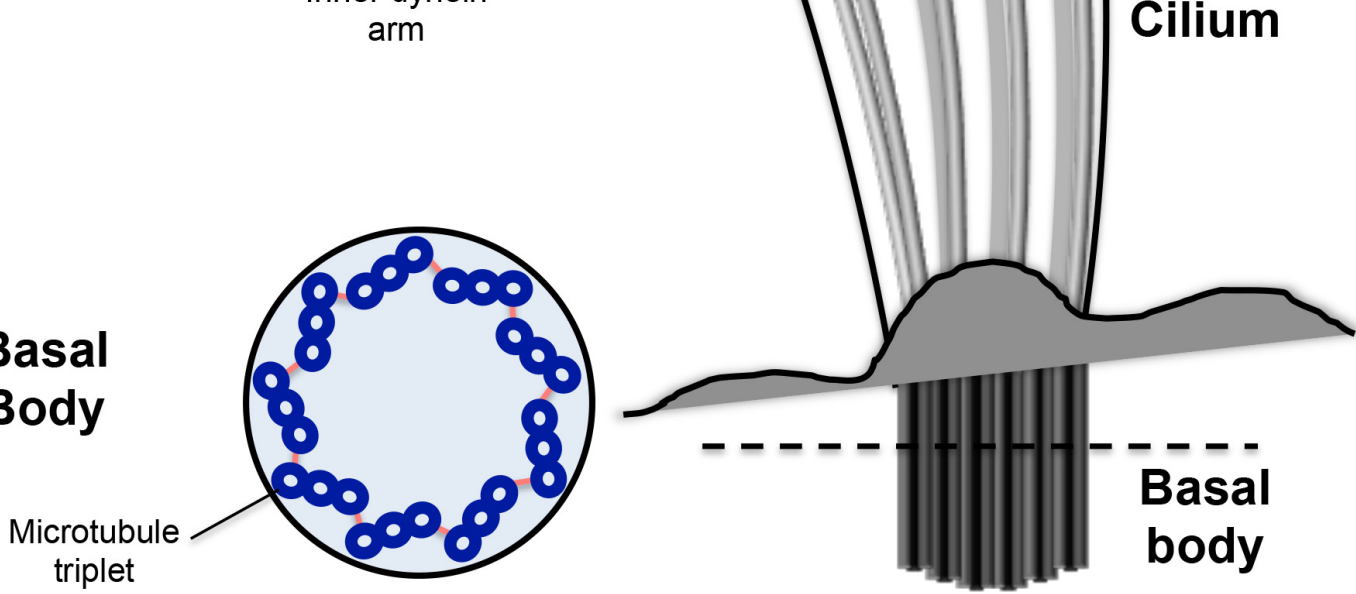

A. Scanning electron micrograph of mouse nodal cilia (image reproduced with permission from Shigenori Nonaka). B. Motile cilia are usually found at a density of several hundred per cell, as shown in this scanning electron micrograph of the mammalian trachea (image from [102]). C. Primary cilia are typically one per cell, as exemplified by primary cilia in renal tubule epithelia (image from [102]). D. Schematic representation of a cilium, with cross sections at the distal end showing the microtubule arrangements in the nodal, motile and non-motile (primary) cilia, and the basal body at the apical side of the cell. DRC, dynein regulatory complex.

shown that the proteins responsible for autosomal dominant polycystic kidney disease also localized to the renal primary cilia in healthy cells, and were involved in calcium conductance [6,7], while mutations discovered in genes encoding basal body and axonemal proteins in patients with the pleiotropic Bardet-Biedl syndrome phenotype highlighted the near ubiquitous critical roles of cilia across tissues [8]. It is now wellestablished that primary, non-motile, cilia play crucial roles in facilitating several signaling pathways, such as Wnt and Hedgehog signaling, and can also function as chemosensory, mechanosensory and photosensory 
mediators [9-12]. For several years, only non-motile cilia were thought to be sensory organelles. However, recent observations have shown that motile cilia can also have chemosensory functions $[13,14]$.

The ability of motile cilia to move or "beat" is due to the differences in microtubule composition when compared to immotile primary cilia (Figure 1D). All cilia are composed of a microtubule-core structure, the axoneme, and are encased in a membrane that is continuous with the plasma membrane. Ciliary microtubule formation is nucleated at the basal body, an anchoring structure at the base of the cilium that originates from the centrioles. Axoneme elongation occurs exclusively at the distal end, away from the base [15]. An intraflagellar transport (IFT) [16] system, consisting of several raft and motor proteins that move bi-directionally along the axoneme, is used to transport protein components from the cytoplasm to the ciliary tip. There are nine microtubule doublets connected by nexin links that circle the periphery of the cilium. Motile cilia have one microtubule doublet in the center (the central pair), generating a 9+2 arrangement that is not found in non-motile cilia (which have a $9+0$ arrangement). Motile cilia also have two dynein arms, an inner and an outer (IDAs and ODAs, respectively), along the length of each microtubule doublet, which hydrolyze ATP to generate movement; these are also absent in non-motile cilia. A third category of cilia that shows characteristics intermediate between the two traditionally defined groups have been described at the embryonic node, a structure critical for establishing the first break of laterality in the body plan [17]. These "nodal cilia" have a 9+0 arrangement and dynein arms, facilitating a rotational movement [18], which is different to the planar beating of motile cilia in other tissues [19]. Individuals with PCD have defects in the function of both motile and also nodal cilia, suggesting that similar mechanisms must lead to the rotational and beating movements.

A major challenge in the management of PCD is obtaining early diagnosis. Patients affected with PCD present primarily with neonatal respiratory distress and chronic sinopulmonary disease that may be accompanied by organ laterality defects (heterotaxy) and, later, male infertility [20]. The sinopulmonary symptoms of PCD can be confused with other congenital diseases, such as cystic fibrosis (incidence of 1:3500 births in populations of European descent) [21]. In the presence of clinical symptoms, a PCD diagnosis can be made through examination of the respiratory ciliary ultrastructure via electron microscopy, measurement of nasal nitric oxide levels, which are typically reduced in PCD patients [22-24], and functional testing of pattern and frequency of ciliary movement using high-speed video imaging [25]. However, the current diagnostic methods have significant drawbacks. PCD is genetically heterogeneous, with $>30$ causative genes reported (Table 1 ), accounting for $\sim 65 \%$ of PCD cases [20]. Thus, for genetic testing to become a comprehensive diagnostic tool, additional genes need to be uncovered to account for PCD in the remaining $35 \%$ of patients.

Here, we give an overview of PCD as a clinically distinct ciliopathy; we highlight the advantages and disadvantages of the currently used diagnostic methods; and we discuss how PCD gene discovery has improved our understanding of motile ciliary assembly.

\section{PCD: a motile cilia disease}

Motile cilia are found on cells lining the airways of the nasal cavity, middle ear, paranasal sinuses and the lower respiratory tract [26]. Consistent with these areas of function, PCD patients suffer from numerous respiratory problems. In addition, motile cilia are found on brain ventricular ependymal cells, and also line the fallopian tubes in women. Thus, although less common than other PCD symptoms, reduced female fertility [27], possibly increased risk of ectopic pregnancy $[28,29]$ and hydrocephalus have been noted in some PCD patients [30-35]. Most PCD symptoms can evolve into serious health problems [36]. Bronchiectasis, or lung disease, is an almost universal outcome of chronic sinusitis in PCD patients and can require lung transplantation [37], and chronic middle ear infections can lead to transient or permanent hearing loss [38,39]. The presence of heterotaxy or complex changes to the arrangement of organs ( $12 \%$ of PCD patients) is also associated with complex cardiac malformations requiring surgery $[37,40]$. Early diagnosis of PCD and early treatment may help ameliorate some symptoms, and also prevent deterioration of lung function through regular physiotherapy and antibiotic treatment [41].

In some instances, PCD can co-segregate with X-linked mental retardation caused by mutations in OFD1 (oralfacial-digital type 1), or with X-linked retinitis pigmentosa caused by RPGR depletion (Table 1) [42-45]. Furthermore, a PCD-like phenotype caused by reduced generation of multiple motile cilia (RGMC) has been described, which is characterized by sinopulmonary symptoms and fertility defects similar to those observed in PCD patients $[46,47]$. The residual motile cilia in RGMC caused by mutations in CCNO show a normal ciliary beat [46], while the few remaining motile cilia in patients with RGMC caused by MCIDAS mutations are immotile [47]. However, no situs defects have been observed in any patients with RGMC, thus suggesting that the function of nodal cilia is intact. 


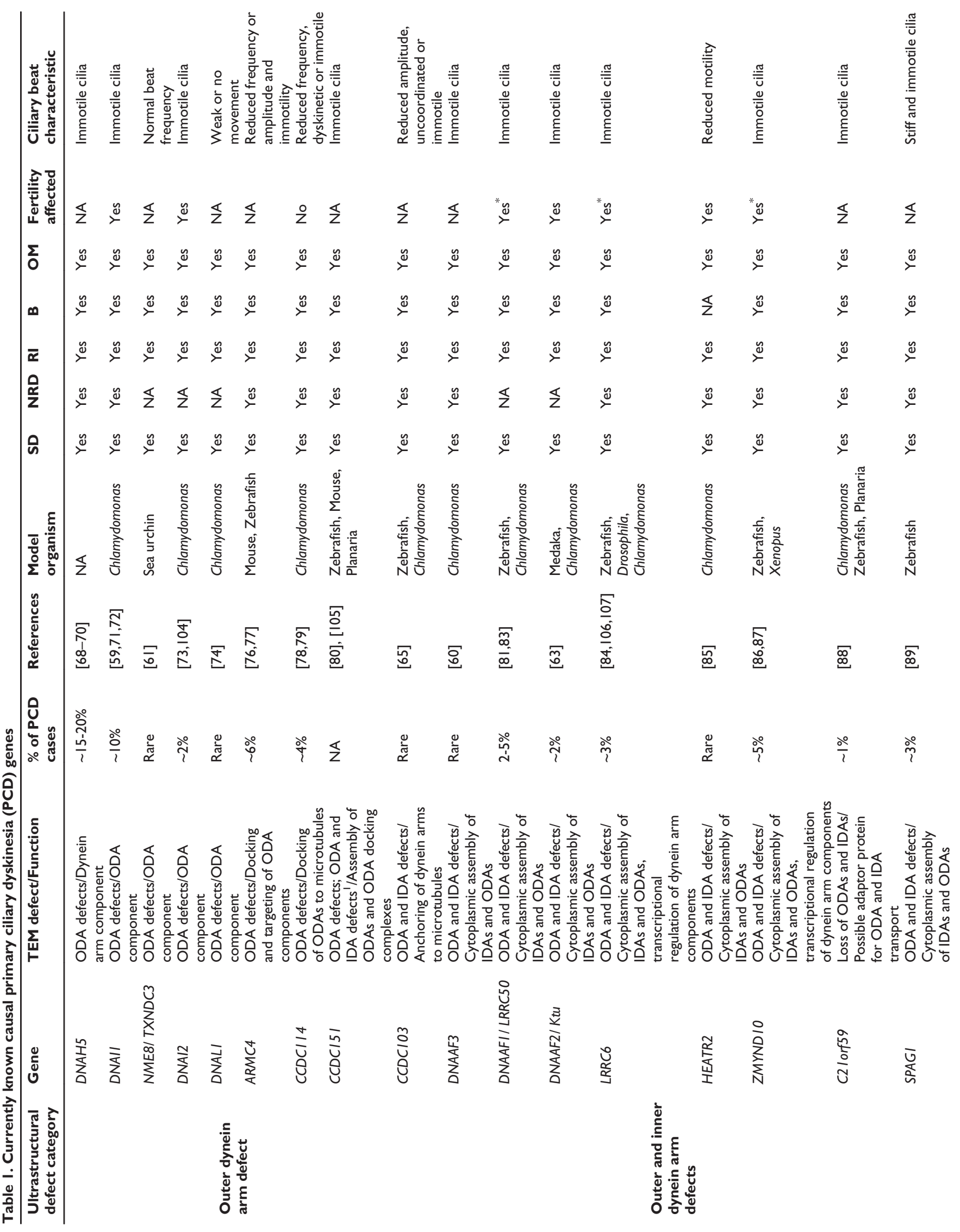


In

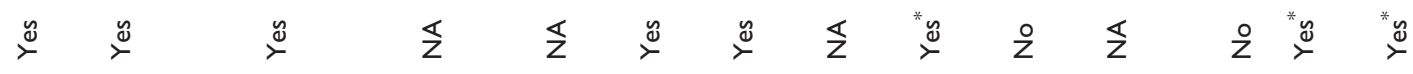

๖

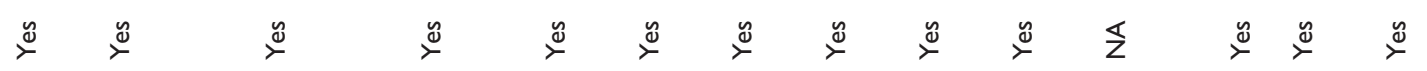

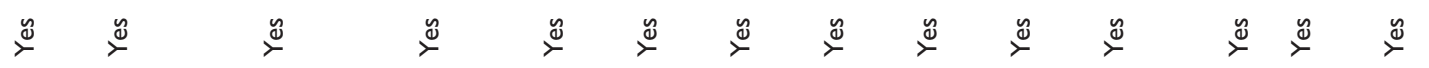

๖

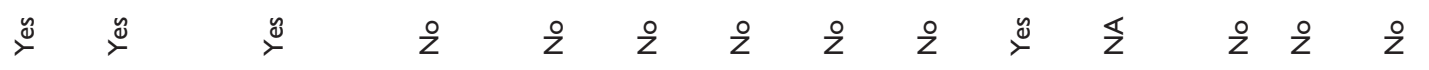

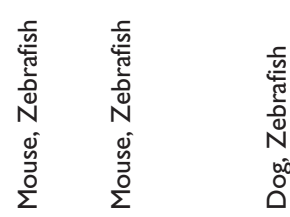

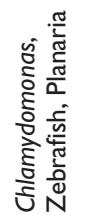

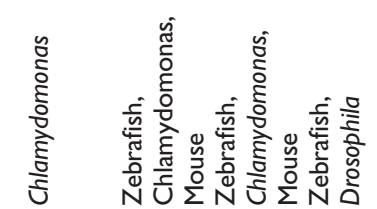

壬

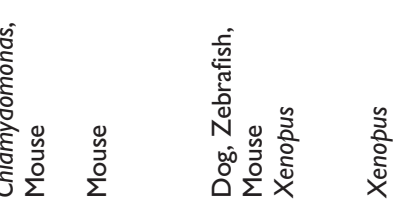

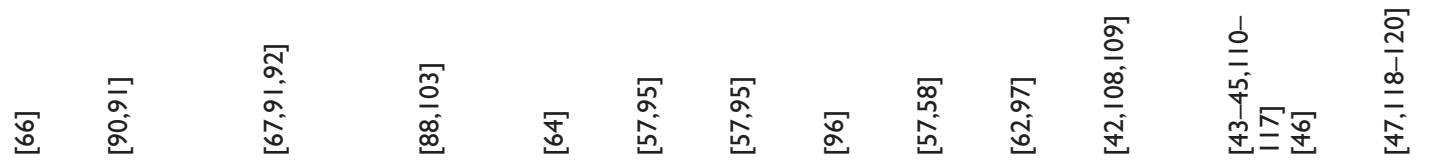

ウ̊ำ

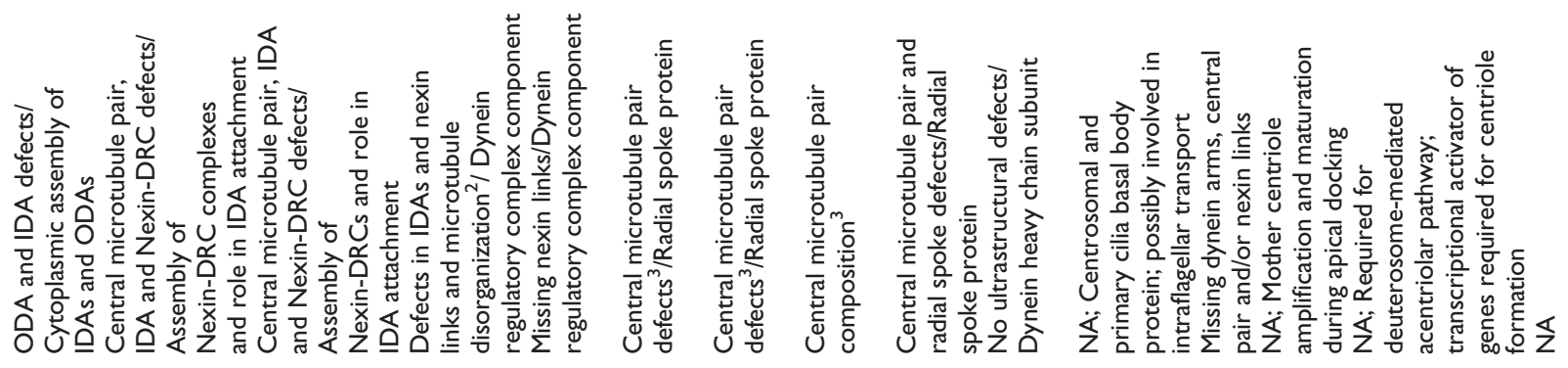

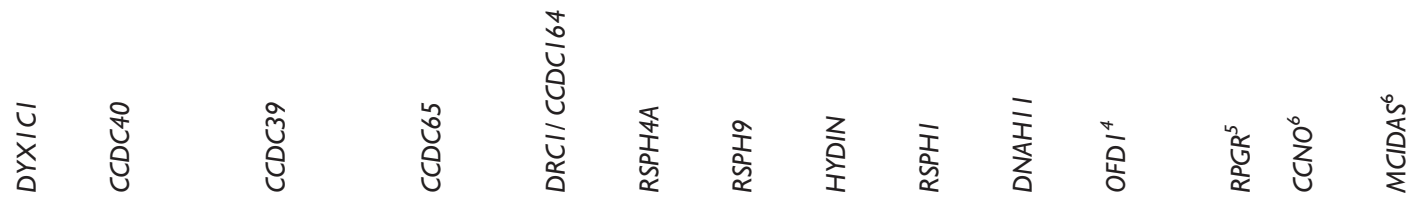
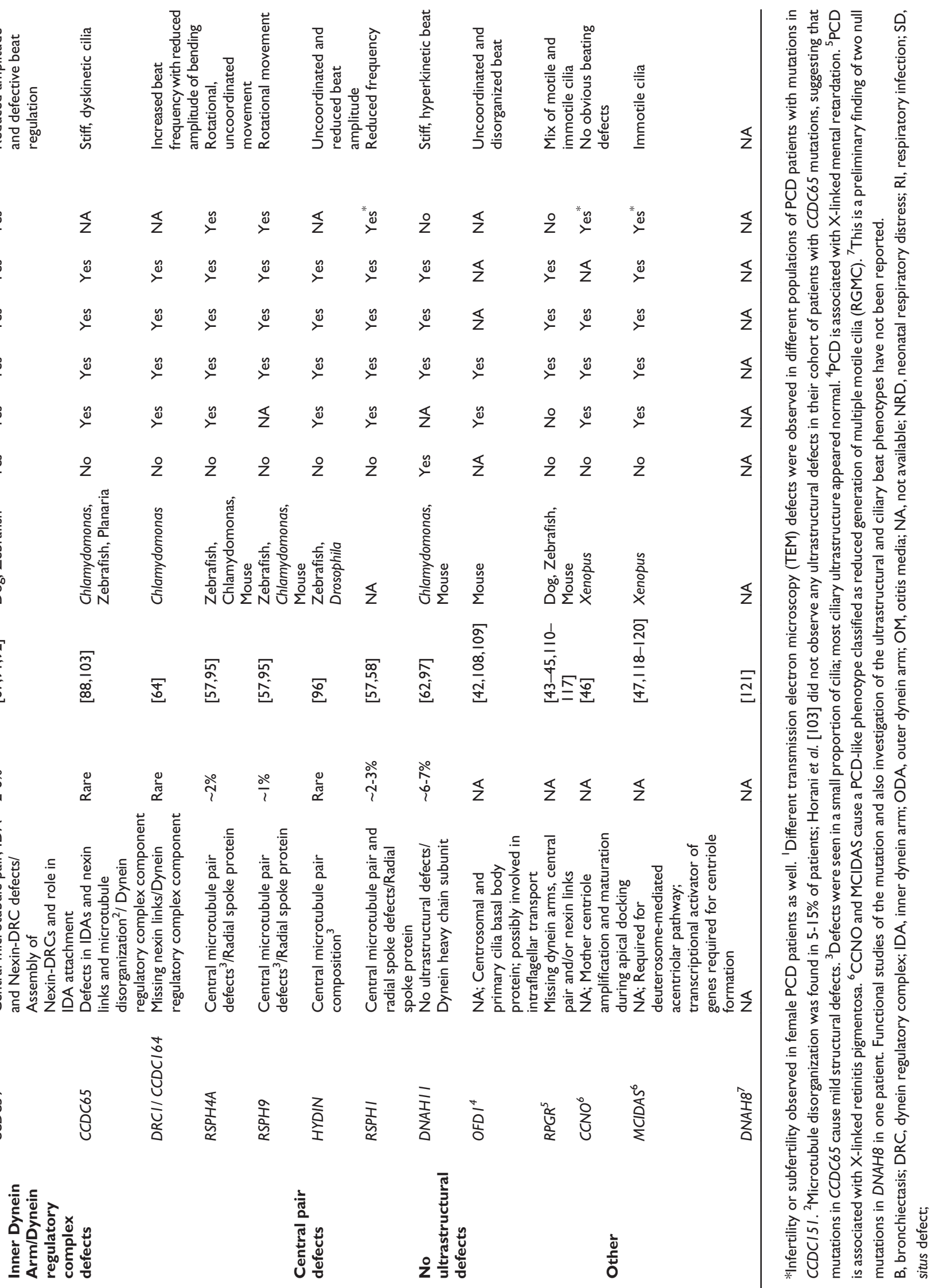


\section{Diagnosing PCD}

The similarity of the respiratory symptoms of PCD with common childhood problems, and the lack of awareness of this rare disorder (prevalence of $\sim 1$ in 10,000) [48] often impede early diagnosis. A recent study reported that the median age at diagnosis was $\sim 5.3$ years [49]. By this time, there can already be considerable damage to the lung tissue in affected children if untreated $[37,50]$. There are several diagnostic methods currently used. Transmission electron microscopy (TEM) of cilia from nasal brushings can identify defects in the ciliary structure, such as defective ODAs or disorganized microtubules [51]. However, since $30 \%$ of PCD patients do not show defects in ciliary structure [52,53], this method cannot be used as an exclusive means to diagnose the disease. Nasal brushings can be analyzed directly or can also be maintained in cell culture to assess ciliary movement by high-speed video microscopy. However, such analyses require specialized personnel and laboratories (as does TEM) to look at cilia structure, and are not readily accessible to all patients. In addition, ciliary dysfunction can also be acquired from infections that result in inflammation, known as secondary ciliary dyskinesia (SCD) [54-56]. Therefore, it is important to distinguish whether abnormalities in ciliary structure or function are due to PCD or SCD. A relatively simple screening method is measurement of nitric oxide (NO) levels in the nasal passage, which are reduced typically in PCD patients compared to healthy individuals. However, other conditions, such as cystic fibrosis and severe sinusitis, can also cause abnormally low levels of $\mathrm{NO}$, and the range of nasal $\mathrm{NO}$ values that distinguish between PCD and these other conditions are yet to be standardized [24]. In addition, some PCDcausing mutations may not result in nasal NO levels low enough to offer a conclusive diagnosis $[57,58]$. Therefore, this test can provide a first pass screen for PCD in children $>5$ years of age, rather than a diagnosis of the disorder. Finally, DNA sequencing to identify causal mutations is becoming the benchmark for diagnosis of several genetic disorders. The applicability of clinical genetic testing for PCD diagnosis is currently limited by the fact that PCD is highly genetically heterogeneous.

\section{Genetics of PCD}

PCD is inherited primarily in an autosomal recessive manner. The first gene shown to be mutated in individuals with PCD was DNAI1, encoding an axonemal dynein intermediate chain [59]. Pennarun et al. used a candidate gene approach to screen a PCD cohort for DNAI1 mutations because a Chlamydomonas reinhardtii mutant bearing mutations in the orthologous gene showed flagella with a TEM defect affecting ODAs similar to that observed in some PCD patients [59]. PCD-related phenotypes uncovered initially and studied in model organisms, such as Chlamydomonas, medaka, zebrafish, sea urchins, Xenopus, mice and even dogs have led to the sequencing and identification of several causal PCD genes [60-67] (Table 1). Not surprisingly, many of these genes are structural components of the axoneme, involved in the composition of the ODAs or their attachment to microtubules (e.g. DNAH5, TXNDC3, DNAI2, DNAL1, $A R M C 4, C C D C 114$, and CCDC151). Mutations in these genes result typically in the complete or partial absence of the ODAs as observed by TEM (Figure 2), and corroborated by the complete or partial absence of ODA markers, such as DNAH5, DNAI2 and DNAH9 in affected axonemes [59,61,65,68-80].

\section{Molecular mechanisms of motile cilia assembly}

In addition to aiding diagnosis, gene discovery has advanced our understanding of basic cellular processes underscoring ciliary biogenesis and function. This is exemplified by the discovery of Ktu/DNAAF2, a locus that, when mutated, causes a loss of both the ODAs and IDAs, but is not detectable in the ciliary fraction of cell extracts [63]. Subsequent experiments showed that Ktu is a cytoplasmic protein involved in the pre-assembly of both ODAs and IDAs before they are transported into the cilium [63] (Figure 2). This discovery introduced a novel paradigm to explain motile cilia formation; prior to the implication of Ktu in PCD, the existing repertoire of causal genes were structural components of the cilium and their site of assembly during ciliogenesis was not known. Following $K t u$, nine other cytoplasmic proteins have been linked causally to PCD (CCDC103, DNAAF3, DNAAF1, LRRC6, HEATR2, ZMYND10, C21orf59, SPAG1, and DYX1C1; Table 1). To date, mutations in all the cytoplasmic dynein assembly factors associated with PCD appear to cause defects in both the IDAs and ODAs according to TEM (Figure 2). This has also been shown by the absence, reduction or mislocalization of ODA and IDA markers, as visualized by the immunofluorescent evaluation of respiratory epithelial cells [60,63,66,81-89].

The identification of genes mutated in PCD cohorts displaying concomitant IDA and central pair defects have elucidated the composition and roles of the nexin-dynein regulatory complex (N-DRC) in ciliary formation (Figure 2). Isolated IDA defects have not been reported in PCD; rather, complete or partial absence of IDAs have thus far been associated with disorganization of peripheral microtubule doublets (in some instances, the central pair of microtubules may also be absent, displaced, or supernumerary). These defects are caused by mutations in proteins involved in the attachment of the IDAs to the microtubules, and in the assembly of the N-DRC (CCDC40, CCDC39, and CCDC65; Table 1) $[64,67,88,90-93]$. Therefore the IDA 
Figure 2. Illustration of ultrastructural ciliary defects

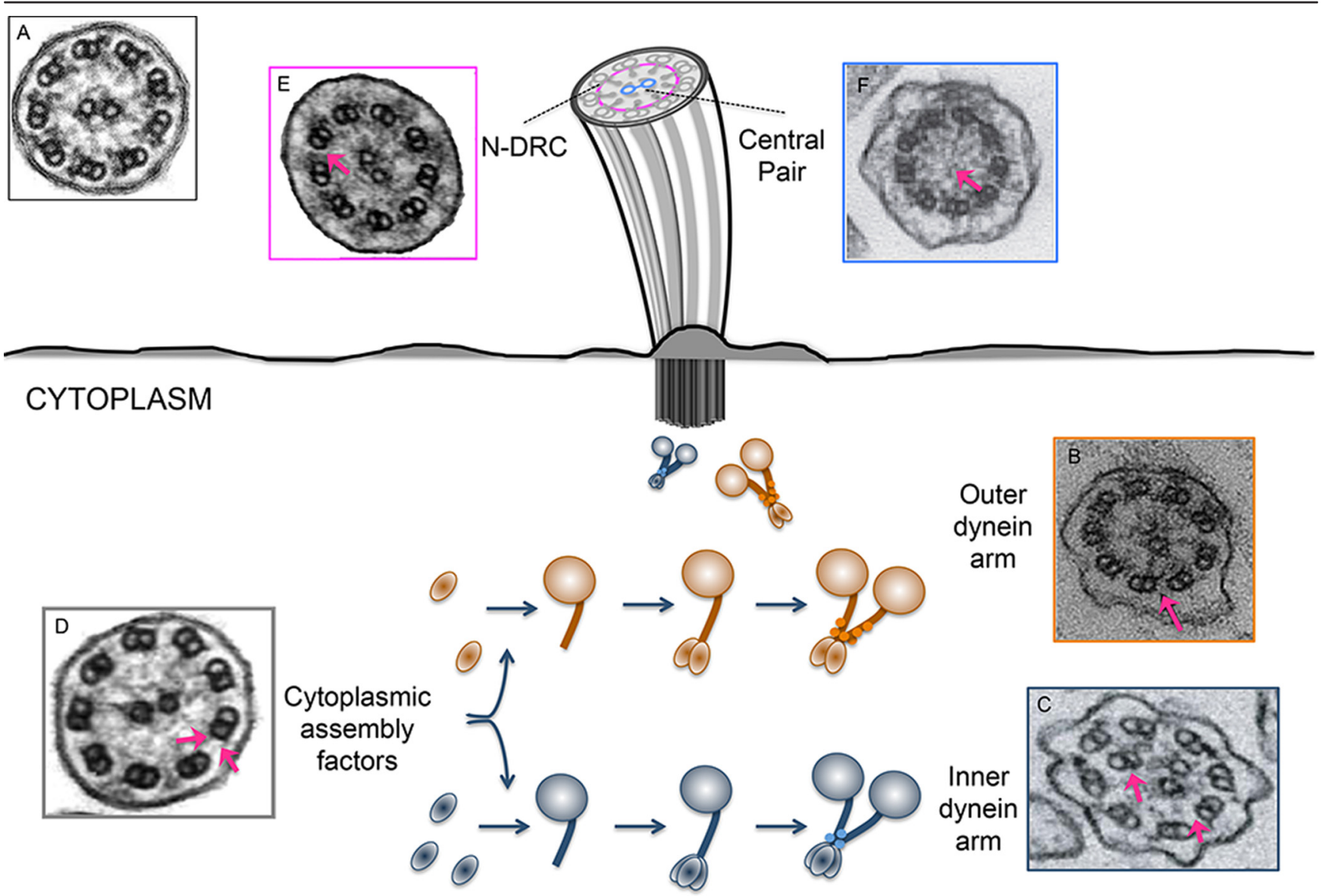

These ultrastructural ciliary defects are characteristic of mutations in genes involved at different steps of cilia assembly and function, including the assembly of the inner and outer dynein arms by cytoplasmic assembly factors. Transmission electron microscopy (TEM) images are shown of a control sample (A, reproduced with permission from Elsevier) and patients with mutations in the following: B. DNAH5, showing defective outer dynein arms (ODAs) (reproduced with permission from Elsevier), C. CCDC40, showing defective inner dynein arms (IDAs) and nexin links (reproduced with permission from Nature Publishing Group), D. LRRC50, showing missing IDAs and ODAs (reproduced with permission from Elsevier), E. CCDCI 64, showing defects in the nexin- dynein regulatory complex (N-DRC) (reproduced with permission from Nature Publishing Group), and F. RSPHI, showing missing central pair of microtubules (reproduced with permission from Elsevier).

defects are also accompanied by defects in the N-DRC, as visualized by the absence or reduction of N-DRC marker proteins (such as GAS11). This sub-group of PCD proteins is unique because, when rendered dysfunctional, they leave only ODAs unaffected; as a result, the force-generating structures are intact, but lack the proper beat regulation likely conferred by the IDAs, the N-DRC and central pair microtubules [94].

\section{Correlations between genotype, ciliary defect and clinical phenotype}

Mutations in a subset of proteins, primarily the components of the radial spokes (RSPH1, RSPH9, RSPH4a, and HYDIN; Table 1), give rise to abnormalities in the central pair without affecting the ODAs or IDAs (Figure 2). In contrast to individuals displaying the gamut of classic PCD symptoms that are caused by IDA and N-DRC defects, accompanied by central pair aberrations, patients carrying mutations that affect only the central pair of microtubules do not present with laterality defects $[57,58,95,96]$. Notably, accumulating clinical data from this PCD subcohort show that the movement of nasal epithelial cilia carrying a defective central pair of microtubules is circular $[58,95,96]$, distinctly different from the planar beating of healthy cilia. This movement is reminiscent of that of nodal cilia, which do not have a central pair of microtubules [18]. Thus, a credible explanation for an absence of left-right asymmetry defects in patients harboring central pair abnormalities is that nodal cilia exhibit normal movement and beat frequency. 
While ciliary ultrastructural defects are a hallmark of PCD in the majority of patients, a significant fraction of individuals with clinical PCD symptoms present with normal ciliary structure ( $30 \%)$, but abnormal function. Of this subset, conservative estimates indicate that $22 \%$ of patients have biallelic mutations in DNAH11, although one study that also considers the contribution of possibly pathogenic rare alleles estimates that as many as $70 \%$ of patients have candidate causal biallelic variants in this locus $[52,53]$ (Table 1). It is intriguing that this gene codes for a component of the dynein heavy chain, although no adverse effects on ciliary structure, both via TEM or immunofluorescence analysis, have been detected in patient respiratory epithelia. Analysis of ciliary movement from individuals harboring DNAH11 mutation, using high-speed video microscopy, shows a non-flexible and hyperkinetic pattern that is different to the nearly immotile cilia seen in patients with DNAH5 or DNAI1 mutations (abnormal ODA; Figure 2) [97], and more closely resembles that of disrupted N-DRC. The normal ultrastructure of cilia in patients with DNAH11 mutations was a key discovery in PCD biology as it indicated that not all instances of PCD manifested in ciliary structural defects. It also highlighted the need for several diagnostic avenues, such as high-speed microscopy to visualize cilia movement and identification of genetic mutations/lesions in addition to TEM, in providing a clinical diagnosis.

Despite the differences in the ultrastructural phenotypes at the organellar level and the resulting ciliary beat differences in DNAH11 versus DNAH5 or DNAI1 mutation-bearing individuals, loss of function mutations in any of these loci result in the classic PCD phenotype $[52,53,97]$. One notable exception may be the observation by Schwabe et al. [97] that fertility does not seem to be affected in the presence of DNAH11 mutations. Since normal fertility was noted only in one male from one affected family, caution is warranted in concluding that this is a general characteristic of DNAH11 mutations. However, it is possible that effects of ciliary gene mutations differ between motile cilia in respiratory epithelia and sperm flagella. This notion is supported by the reported differences in axoneme composition, specifically the dynein heavy chain subunits, between these two types of cilia [98]. In addition, mutations in another gene (CCDC114) have also been shown to cause PCD without an overt infertility phenotype [78] (Table 1). Together, these observations suggest that the ultrastructural differences resulting from different PCD mutations result in similar end phenotypes in patients, with the noted exceptions of situs defects and fertility.
Although an individual's clinical PCD symptoms may not be sufficient to elucidate which group of genes may harbor mutations, the TEM and immunofluorescence analysis of cilia structure can be helpful in narrowing the pool of candidates. For example, defects in both ODAs and IDAs are indicative of underlying mutations in cytoplasmic dynein assembly factors; and the absence of any ultrastructural defect in the presence of PCDlike symptoms suggests the increased likelihood of mutations in DNAH11 or other genes that have been associated with subtle or unappreciable TEM defects, such as CCDC65, CCDC164 or HYDIN. Correlations of axonemal ultrastructure and functional output data with gene groups stratified by function have been used to direct sequencing efforts and facilitate diagnosis $[57,69,76,84]$.

The majority of mutations reported in PCD patients are null alleles (frameshift or nonsense). There are few instances of mutations that have been tested and characterized as hypomorphic. Moore et al. [87] characterized a missense mutation in ZMYND1 (V16G) as a hypomorph in cell-based assays and in Drosophila models. However, even though cilia from patients homozygous for V16G retained some motility, the clinical phenotypes of these patients were similar to those of PCD individuals harboring null alleles. Similarly, Knowles et al. [79] reported leaky expression of the full-length mRNA in a patient with two splicing mutations in CCDC114, suggesting that the alleles had residual function, although the patient's phenotype was indistinguishable from that of patients with DNAI1 or DNAH5 mutations. Panizzi et al. [65] determined, through functional studies in zebrafish, that a missense mutation in CCDC103 (H154P) identified in PCD patients was a hypomorph. Even so, the clinical data from the CCDC103 mutation-bearing patients were consistent with full PCD diagnostic criteria. Together, these observations suggest that the tolerance threshold for motile ciliary perturbations is low, and that correlations between PCD protein function and disease phenotypes may be imperfect.

A study comparing different types of mutations in DNAH5 concluded that two mutations causing premature termination of translation resulted in a complete loss of the ODAs in those patients, while cilia with a splicing mutation in DNAH5 had a partial absence of ODAs [99]. However, how these ultrastructural defects correlated with the clinical symptoms of the patients carrying these mutations was not provided. Therefore, more studies that compare the severity of mutations through functional tests and the clinical phenotypes of 
patients are needed to understand the contributions of mild versus severe mutations to the PCD phenotype.

\section{Concluding remarks}

Hundreds of genes have been implicated in motile cilia structure and function [100], thus representing a sizeable repertoire of candidate genes that could be involved in PCD etiology. Gene discovery in the PCD field has accelerated, as whole exome and whole genome sequencing (WES/WGS) have become increasingly affordable and widely used. Over half of the causal PCD genes (16) have been uncovered within the last 4 years, compared to nine that were implicated in the 11 years after the association of DNAI1 with the disease (Table 1). As more patient cohorts are sequenced, we will likely discover new candidate genes to account for the $35 \%$ of the remaining patient population with an unresolved molecular genetic diagnosis.

Despite the genetic heterogeneity underlying PCD, the patient phenotypes reported are largely similar, with few examples of gene- or mutation-specific differences (Table 1). The exceptions include an absence of situs defects and infertility $[57,78,95,96]$. In a recent study, Knowles et al. [58] observed that their cohort of patients with mutations in RSPH1 had mild PCD phenotypes, which included a lower incidence of neonatal respiratory distress, later onset of respiratory problems, better lung function and higher nasal $\mathrm{NO}$ levels when compared to patients with mutations in DNAH11. In general, the phenotype of patients with RSPH1 mutations is milder, compared to PCD patients with mutations that cause ultrastructural defects affecting the inner or outer dynein arms $[37,58]$. An earlier study, however, did not find significantly milder phenotypes in patients with RSPH1 mutations [57]. This discrepancy might be due to differences in clinical ascertainment. Nevertheless, the RSPH1 observation is notable; it is among the few reports of a possible genotype-phenotype correlation in PCD and it highlights the importance of having comprehensive and quantitative clinical data to enable comparisons between groups of patients.

In comparison to the primary ciliopathies, the clinical homogeneity of PCD is striking. We note with interest that a significant proportion of variants associated causally with PCD genes are null mutations. Is this observation due to an ascertainment bias in which severe, syndromic patients undergo molecular analysis? PCD cohorts in genetic studies are diagnosed typically based on clinical symptoms and cilia structure/function analysis. However, this approach can be problematic, as many of these symptoms can be due to other causes. It is possible that residual activity in many of the PCDcausing genes is sufficient to spare the organism from pathology, or that the hypomorph of PCD might be a completely different disorder, a paradigm well-described for the primary ciliopathies [101].

Consistent with the lack of clinical variability in PCD, and despite the accumulating evidence for oligogenic phenomena contributing to the phenotypic variability observed in the primary ciliopathies, genetic interactions in PCD have been essentially unexplored. One possibility is that mutations in PCD genes have an "all or none" effect on motile ciliary function, such that an increase in the number of mutations in ciliary genes is not expected to exacerbate the clinical phenotype. The fact that mutations in most causal PCD genes produce the classic PCD phenotype argues in favor of this possibility. Alternatively, the concept of ciliary gene mutational load cannot be excluded as a contributor to the phenotype in some patients. The exacerbation of the phenotypic severity or the manifestation of certain endophenotypes by the genetic interaction of two or more ciliary gene mutations is a well-established phenomenon in other ciliopathies [101,102]. To appreciate what role, if any, genetic interaction plays in PCD, we need a detailed understanding of genotypephenotype correlations both within PCD pedigrees with multiple affected individuals, and also among unrelated individuals who harbor mutations at the same locus. Additionally, unbiased approaches, such as WES and WGS, are required to identify the primary "driver" of PCD mutations as well as potential phenotypic modifier mutations.

Looking forward, a key goal is to identify more causal PCD genes that can improve the diagnostic power when combined with other approaches, such as TEM and ciliary function analysis. Moreover, the continued standardization and improved quantitative means of reporting clinical phenotyping will aid our ability to make informed correlations between mutational burden and phenotype, both within and across families. We anticipate that the continued intersection of robust in vivo and in vitro tools with comprehensive genetic and clinical data will ultimately decrease the time to diagnosis and improve clinical outcomes for this lifethreatening disorder.

\section{Abbreviations}

IDA, inner dynein arm; N-DRC, nexin-dynein regulatory complex; NO, nitric oxide; ODA, outer dynein arm; PCD, primary ciliary dyskinesia; RGMC, reduced generation of multiple motile cilia; $\mathrm{SCD}$, secondary ciliary dyskinesia; 
TEM, transmission electron microscopy; WES, whole exome sequencing; WGS, whole genome sequencing.

\section{Disclosures}

The authors declare that they have no disclosures.

\section{Acknowledgments}

This work was supported by the grants R01DK072301 (Nicholas Katsanis and Erica E. Davis); R01HD04260 and R01DK075972 (Nicholas Katsanis); R01EY021872 (Erica E. Davis); and funding from EU 7th FP under GA nr. 241955, project SYSCILIA (Nicholas Katsanis and Erica E. Davis). Nicholas Katsanis is a Distinguished Brumley Professor.

\section{References}

I. Gibbons IR: Cilia and flagella of eukaryotes. The Journal of cell biology I98I, 91:107s-I24s.

2. Afzelius BA: A human syndrome caused by immotile cilia. Science (New York, N.Y.) 1976, 193:3 I7-9.

3. Eliasson R, Mossberg B, Camner P, Afzelius BA: The immotile-cilia syndrome. A congenital ciliary abnormality as an etiologic factor in chronic airway infections and male sterility. The New England journal of medicine 1977, 297: 1-6.

4. Sleigh MA: Primary Ciliary Dyskinesia. The Lancet I98I, 3 I 8:476.

5. Pazour G], Dickert BL, Vucica Y, Seeley ES, Rosenbaum JL, Witman GB, Cole DG: Chlamydomonas IFT88 and its mouse homologue, polycystic kidney disease gene $\operatorname{tg} 737$, are required for assembly of cilia and flagella. The Journal of cell biology 2000, |5 I:709-18.

6. Pazour GJ, San Agustin, Jovenal T, Follit JA, Rosenbaum JL, Witman GB: Polycystin-2 localizes to kidney cilia and the ciliary level is elevated in orpk mice with polycystic kidney disease. Current biology: CB 2002, I 2:R378-80.

7. Yoder BK, Hou X, Guay-Woodford LM: The polycystic kidney disease proteins, polycystin-I, polycystin-2, polaris, and cystin, are co-localized in renal cilia. Journal of the American Society of Nephrology: JASN 2002, 13:2508-16.

8. Ansley SJ, Badano JL, Blacque OE, Hill J, Hoskins BE, Leitch CC, Kim JC, Ross AJ, Eichers ER, Teslovich TM, Mah AK, Johnsen RC, Cavender JC, Lewis RA, Leroux MR, Beales PL, Katsanis N: Basal body dysfunction is a likely cause of pleiotropic Bardet-Biedl syndrome. Nature 2003, 425:628-33.

\section{FlOOOPrime} RECOMMENDED

9. Goetz SC, Anderson KV: The primary cilium: a signalling centre during vertebrate development. Nature reviews. Genetics 2010, I I:33 I-44

10. Gerdes JM, Davis EE, Katsanis N: The vertebrate primary cilium in development, homeostasis, and disease. Cell 2009, 137:32-45.

II. Anderson CT, Castillo AB, Brugmann SA, Helms JA, Jacobs CR, Stearns T: Primary cilia: cellular sensors for the skeleton. Anatomical record (Hoboken, N.J.: 2007) 2008, 291:1074-8.

12. Rosenbaum JL, Cole DG, Diener DR: Intraflagellar transport: the eyes have it. The Journal of cell biology 1999, I44:385-8.

13. Shah AS, Ben-Shahar Y, Moninger TO, Kline JN, Welsh MJ: Motile cilia of human airway epithelia are chemosensory. Science (New York, N.Y.) 2009, 325: || $3 \mid-4$.

\section{FlOOOPrime} RECOMMENDED

14. Takeda S, Narita K: Structure and function of vertebrate cilia, towards a new taxonomy. Differentiation; research in biological diversity 2012, 83:S4-II.
I5. Rosenbaum JL, Child FM: Flagellar regeneration in protozoan flagellates. The Journal of cell biology 1967, 34:345-64.

16. Kozminski KG, Johnson KA, Forscher P, Rosenbaum JL: A motility in the eukaryotic flagellum unrelated to flagellar beating. Proceedings of the National Academy of Sciences of the United States of America 1993, 90:5519-23.

17. Harvey RP: Links in the left/right axial pathway. Cell 1998, 94:273-6.

18. Okada Y, Takeda S, Tanaka Y, Izpisúa Belmonte J, Hirokawa N: Mechanism of nodal flow: a conserved symmetry breaking event in left-right axis determination. Cell 2005, I 2 I:633-44.

\section{FlOOOPrime
RECOMMENDED}

19. Blake JR, Sleigh MA: Mechanics of ciliary locomotion. Biological reviews of the Cambridge Philosophical Society 1974, 49:85-I25.

20. Knowles MR, Daniels LA, Davis SD, Zariwala MA, Leigh MW: Primary ciliary dyskinesia. Recent advances in diagnostics, genetics, and characterization of clinical disease. American journal of respiratory and critical care medicine 2013, 188:9/3-22.

21. Kosorok MR, Wei WH, Farrell PM: The incidence of cystic fibrosis. Statistics in medicine 1998, I5:449-62.

22. Lundberg JO, Weitzberg E, Nordvall SL, Kuylenstierna R, Lundberg JM, Alving K: Primarily nasal origin of exhaled nitric oxide and absence in Kartagener's syndrome. The European respiratory journal 1994, 7:150I-4.

23. Wodehouse T, Kharitonov SA, Mackay IS, Barnes PJ, Wilson R, Cole P]: Nasal nitric oxide measurements for the screening of primary ciliary dyskinesia. The European respiratory journal 2003, $21: 43-7$.

24. Leigh MW, Hazucha MJ, Chawla KK, Baker BR, Shapiro AJ, Brown DE, Lavange LM, Horton BJ, Qaqish B, Carson JL, Davis SD, Dell SD, Ferkol TW, Atkinson J], Olivier KN, Sagel SD, Rosenfeld M, Milla C, Lee H, Krischer J, Zariwala MA, Knowles MR: Standardizing nasal nitric oxide measurement as a test for primary ciliary dyskinesia. Annals of the American Thoracic Society 2013, 10:574-8I.

25. Stannard WA, Chilvers MA, Rutman AR, Williams CD, O'Callaghan C: Diagnostic testing of patients suspected of primary ciliary dyskinesia. American journal of respiratory and critical care medicine 2010, I8I:307-14.

\section{FlOOOPrime}

\section{RECOMMENDED}

26. Yoder BK: Ciliary function in mammalian development. Ist edition. San Diego, London: Elsevier/Academic Press; 2008 [Current topics in developmental biology, v. 85].

27. Afzelius BA, Eliasson R: Male and female infertility problems in the immotile-cilia syndrome. European journal of respiratory diseases. Supplement 1983, 127:144-7.

28. Lin TK, Lee RK, Su JT, Liu WY, Lin MH, Hwu YM: A successful pregnancy with in vitro fertilization and embryo transfer in an infertile woman with Kartagener's syndrome: a case report. Journal of assisted reproduction and genetics 1998, 15:625-7.

29. Blyth $M$, Wellesley D: Ectopic pregnancy in primary ciliary dyskinesia. Journal of obstetrics and gynaecology: the journal of the Institute of Obstetrics and Gynaecology 2008, 28:358.

30. Picco P, Leveratto L, Cama A, Vigliarolo MA, Levato GL, Gattorno M, Zammarchi E, Donati MA: Immotile cilia syndrome associated with hydrocephalus and precocious puberty: a case report. European journal of pediatric surgery: official journal of Austrian Association of Pediatric Surgery 1993, 3(Suppl I):20-I.

3I. Greenstone MA, Jones RW, Dewar A, Neville BG, Cole PJ: Hydrocephalus and primary ciliary dyskinesia. Archives of disease in childhood 1984, 59:48I-2

32. al-Shroof M, Karnik AM, Karnik AA, Longshore J, Sliman NA, Khan FA: Ciliary dyskinesia associated with hydrocephalus and mental retardation in a Jordanian family. Mayo Clinic proceedings 200I, 76:1219-24.

33. Wessels MW, den Hollander, Nicolette S, Willems PJ: Mild fetal cerebral ventriculomegaly as a prenatal sonographic marker for Kartagener syndrome. Prenatal diagnosis 2003, 23:239-42. 
34. De Santi MM, Magni A, Valletta EA, Gardi C, Lungarella G: Hydrocephalus, bronchiectasis, and ciliary aplasia. Archives of disease in childhood 1990, 65:543-4.

35. Kosaki K, Ikeda K, Miyakoshi K, Ueno M, Kosaki R, Takahashi D, Tanaka M, Torikata C, Yoshimura Y, Takahashi T: Absent inner dynein arms in a fetus with familial hydrocephalus-situs abnormality. American journal of medical genetics. Part A 2004, I29A:308-II

36. Dell SD: Primary ciliary dyskinesia: Myths and realities. Paediatrics \& child health 2008, 13:668-70.

37. Kennedy MP, Noone PG, Leigh MW, Zariwala MA, Minnix SL, Knowles MR, Molina PL: High-resolution CT of patients with primary ciliary dyskinesia. AJR. American journal of roentgenology 2007, 188: 1232-8.

38. Campbell RG, Birman CS, Morgan L: Management of otitis media with effusion in children with primary ciliary dyskinesia: a literature review. International journal of pediatric otorhinolaryngology 2009, 73:1630-8.

39. Simpson SA, Thomas $\mathrm{CL}$, van der Linden $\mathrm{MK}$, Macmillan $\mathrm{H}$, van der Wouden JC, Butler C: Identification of children in the first four years of life for early treatment for otitis media with effusion. The Cochrane database of systematic reviews 2007:CD004I63.

40. Shapiro AJ, Davis SD, Ferkol T, Dell SD, Rosenfeld M, Olivier KN, Sagel SD, Milla C, Zariwala MA, Wolf W, Carson JL, Hazucha MJ, Burns K, Robinson B, Knowles MR, Leigh MW: Laterality defects other than situs inversus totalis in primary ciliary dyskinesia: insights into situs ambiguus and heterotaxy. Chest 2014, 146: I 1 76-86.

\section{FlOOOPrime}

RECOMMENDED

4I. Ellerman A, Bisgaard $\mathrm{H}$ : Longitudinal study of lung function in a cohort of primary ciliary dyskinesia. The European respiratory journal 1997, 10:2376-9.

42. Budny B, Chen W, Omran H, Fliegauf M, Tzschach A, Wisniewska M, Jensen LR, Raynaud M, Shoichet SA, Badura M, Lenzner S, LatosBielenska A, Ropers $H$ : A novel $X$-linked recessive mental retardation syndrome comprising macrocephaly and ciliary dysfunction is allelic to oral-facial-digital type I syndrome. Human genetics 2006, 120:171-8.

43. lannaccone A, Breuer DK, Wang XF, Kuo SF, Normando EM, Filippova E, Baldi A, Hiriyanna S, MacDonald CB, Baldi F, Cosgrove D, Morton CC, Swaroop A, Jablonski MM: Clinical and immunohistochemical evidence for an $X$ linked retinitis pigmentosa syndrome with recurrent infections and hearing loss in association with an RPGR mutation. Journal of medical genetics 2003, 40:el I8.

44. Moore A, Escudier E, Roger G, Tamalet A, Pelosse B, Marlin S, Clément A, Geremek M, Delaisi B, Bridoux A, Coste A, Witt M, Duriez B, Amselem S: RPGR is mutated in patients with a complex $X$ linked phenotype combining primary ciliary dyskinesia and retinitis pigmentosa. Journal of medical genetics 2006, 43:326-33.

45. Zito I, Downes SM, Patel RJ, Cheetham ME, Ebenezer ND, Jenkins SA, Bhattacharya SS, Webster AR, Holder GE, Bird AC, Bamiou DE, Hardcastle AJ: RPGR mutation associated with retinitis pigmentosa, impaired hearing, and sinorespiratory infections. Journal of medical genetics 2003, 40:609-I5.

46. Wallmeier J, Al-Mutairi DA, Chen C, Loges NT, Pennekamp P, Menchen T, Ma L, Shamseldin HE, Olbrich H, Dougherty GW, Werner C, Alsabah BH, Köhler G, Jaspers M, Boon M, Griese M, Schmitt-Grohé S, Zimmermann T, Koerner-Rettberg C, Horak E, Kintner C, Alkuraya FS, Omran H: Mutations in CCNO result in congenital mucociliary clearance disorder with reduced generation of multiple motile cilia. Nature genetics 2014, 46:646-5I.

\section{FlOOOPrime}

RECOMMENDED

47. Boon $M$, Wallmeier J, Ma L, Loges NT, Jaspers $M$, Olbrich $H$, Dougherty GW, Raidt J, Werner C, Amirav I, Hevroni A, Abitbul R, Avital A, Soferman R, Wessels M, O'Callaghan C, Chung Eddie MK,
Rutman A, Hirst RA, Moya E, Mitchison HM, van Daele S, Boeck K de, Jorissen M, Kintner C, Cuppens H, Omran H: MCIDAS mutations result in a mucociliary clearance disorder with reduced generation of multiple motile cilia. Nature communications 2014 , 5:4418.

\section{FlOOOPrime
RECOMMENDED}

48. Afzelius BA, Stenram U: Prevalence and genetics of immotilecilia syndrome and left-handedness. The International journal of developmental biology 2006, 50:57I-3.

49. Kuehni CE, Frischer T, Strippoli MF, Maurer E, Bush A, Nielsen KG, Escribano A, Lucas JSA, Yiallouros P, Omran H, Eber E, O'Callaghan C, Snijders D, Barbato A: Factors influencing age at diagnosis of primary ciliary dyskinesia in European children. The European respiratory journal 2010, 36:1248-58.

\section{FIOOOPrime
RECOMMENDED}

50. Marthin JK, Petersen N, Skovgaard LT, Nielsen KG: Lung function in patients with primary ciliary dyskinesia: a cross-sectional and 3-decade longitudinal study. American journal of respiratory and critical care medicine 2010, 181:1262-8.

\section{FIOOOPRime}

5I. Bush A, Chodhari R, Collins N, Copeland F, Hall P, Harcourt J, Hariri M, Hogg C, Lucas J, Mitchison HM, O'Callaghan C, Phillips G: Primary ciliary dyskinesia: current state of the art. Archives of disease in childhood 2007, 92: I I36-40.

52. Knowles MR, Leigh MW, Carson JL, Davis SD, Dell SD, Ferkol TW, Olivier KN, Sagel SD, Rosenfeld M, Burns KA, Minnix SL, Armstrong MC, Lori A, Hazucha MJ, Loges NT, Olbrich H, BeckerHeck A, Schmidts M, Werner C, Omran H, Zariwala MA: Mutations of DNAHI I in patients with primary ciliary dyskinesia with normal ciliary ultrastructure. Thorax 2012, 67:433-4I.

\section{FlOOOPrime}

RECOMMENDED

53. Boon M, Smits A, Cuppens H, Jaspers M, Proesmans M, Dupont LJ, Vermeulen FL, van Daele S, Malfroot A, Godding V, Jorissen M, Boeck K de: Primary ciliary dyskinesia: critical evaluation of clinical symptoms and diagnosis in patients with normal and abnormal ultrastructure. Orphanet journal of rare diseases 20I4, 9: I I.

\section{FlOOOPrime
RECOMMENDED}

54. Barbato A, Frischer T, Kuehni CE, Snijders D, Azevedo I, Baktai G, Bartoloni L, Eber E, Escribano A, Haarman E, Hesselmar B, Hogg C, Jorissen M, Lucas J, Nielsen KG, O'Callaghan C, Omran H, Pohunek P, Strippoli MF, Bush A: Primary ciliary dyskinesia: a consensus statement on diagnostic and treatment approaches in children. The European respiratory journal 2009, 34:I264-76.

55. Cornillie FJ, Lauweryns JM, Corbeel L: Atypical bronchial cilia in children with recurrent respiratory tract infections. A comparative ultrastructural study. Pathology, research and practice 1984, 178:595-604.

56. Smallman LA, Gregory J: Ultrastructural abnormalities of cilia in the human respiratory tract. Human pathology 1986, 17:848-55.

57. Kott E, Legendre M, Copin B, Papon J, Dastot-Le Moal F, Montantin G, Duquesnoy P, Piterboth W, Amram D, Bassinet L, Beucher J, Beydon N, Deneuville E, Houdouin V, Journel H, Just J, Nathan N, Tamalet A, Collot N, Jeanson L, Le Gouez M, Vallette B, Vojtek A, Epaud R, Coste A, Clement A, Housset B, Louis B, Escudier E, Amselem S: Loss-of-function mutations in RSPHI cause primary ciliary dyskinesia with central-complex and radialspoke defects. American journal of human genetics 20I3, 93:56I-70.

\section{FlOOOPrime}

58. Knowles MR, Ostrowski LE, Leigh MW, Sears PR, Davis SD, Wolf WE, Hazucha MJ, Carson JL, Olivier KN, Sagel SD, Rosenfeld M, Ferkol TW, Dell SD, Milla CE, Randell SH, Yin W, Sannuti A, Metjian HM, Noone PG, Noone PJ, Olson CA, Patrone MV, Dang H, Lee H, 
Hurd TW, Gee HY, Otto EA, Halbritter J, Kohl S, Kircher M et al.: Mutations in RSPHI cause primary ciliary dyskinesia with a unique clinical and ciliary phenotype. American journal of respiratory and critical care medicine 20|4, I89:707-I7.

\section{FlOOOPRime
RECOMMENDED}

59. Pennarun G, Escudier E, Chapelin C, Bridoux AM, Cacheux V, Roger G, Clément A, Goossens M, Amselem S, Duriez B: Loss-of-function mutations in a human gene related to Chlamydomonas reinhardtii dynein IC78 result in primary ciliary dyskinesia. American journal of human genetics 1999, 65:1508-19.

60. Mitchison HM, Schmidts M, Loges NT, Freshour J, Dritsoula A, Hirst RA, O'Callaghan C, Blau H, Al Dabbagh M, Olbrich H, Beales PL, Yagi T, Mussaffi H, Chung Eddie MK, Omran H, Mitchell DR: Mutations in axonemal dynein assembly factor DNAAF3 cause primary ciliary dyskinesia. Nature genetics 20I2, 44:38I-9, SI-2.

\section{FlOOOPrime}

\section{RECOMMENDED}

61. Duriez B, Duquesnoy P, Escudier E, Bridoux A, Escalier D, Rayet I, Marcos E, Vojtek A, Bercher J, Amselem S: A common variant in combination with a nonsense mutation in a member of the thioredoxin family causes primary ciliary dyskinesia. Proceedings of the National Academy of Sciences of the United States of America 2007, 104:3336-41.

62. Bartoloni L, Blouin J, Pan Y, Gehrig C, Maiti AK, Scamuffa N, Rossier C, Jorissen M, Armengot M, Meeks M, Mitchison HM, Chung Eddie MK, Delozier-Blanchet CD, Craigen WJ, Antonarakis SE: Mutations in the DNAHII (axonemal heavy chain dynein type II) gene cause one form of situs inversus totalis and most likely primary ciliary dyskinesia. Proceedings of the National Academy of Sciences of the United States of America 2002, 99:10282-6.

63. Omran H, Kobayashi D, Olbrich $H$, Tsukahara $T$, Loges NT, Hagiwara H, Zhang Q, Leblond G, O'Toole E, Hara C, Mizuno H, Kawano H, Fliegauf M, Yagi T, Koshida S, Miyawaki A, Zentgraf H, Seithe $H$, Reinhardt R, Watanabe $Y$, Kamiya R, Mitchell DR, Takeda $H$ : $\mathrm{Ktu} / \mathrm{PFI} 3$ is required for cytoplasmic pre-assembly of axonemal dyneins. Nature 2008, 456:6 I I-6.

\section{FlOOOPrime} RECOMMENDED

64. Wirschell M, Olbrich H, Werner C, Tritschler D, Bower R, Sale WS, Loges NT, Pennekamp P, Lindberg S, Stenram U, Carlén B, Horak E, Köhler G, Nürnberg P, Nürnberg G, Porter ME, Omran H: The nexindynein regulatory complex subunit $D R C I$ is essential for motile cilia function in algae and humans. Nature genetics 2013, 45:262-8.

\section{FlOOOPrime}

RECOMMENDED

65. Panizzi IR, Becker-Heck A, Castleman VH, Al-Mutairi DA, Liu Y, Loges NT, Pathak N, Austin-Tse C, Sheridan E, Schmidts M, Olbrich H, Werner C, Häffner K, Hellman N, Chodhari R, Gupta A, KramerZucker A, Olale F, Burdine RD, Schier AF, O'Callaghan C, Chung, Eddie MK, Reinhardt R, Mitchison HM, King SM, Omran H, Drummond IA: CCDCIO3 mutations cause primary ciliary dyskinesia by disrupting assembly of ciliary dynein arms. Nature genetics 2012, 44:7।4-9.

\section{FIOOOPrime \\ RECOMMENDED}

66. Tarkar A, Loges NT, Slagle CE, Francis R, Dougherty GW, Tamayo JV, Shook B, Cantino M, Schwartz D, Jahnke C, Olbrich H, Werner C, Raidt J, Pennekamp P, Abouhamed M, Hjeij R, Köhler G, Griese M, Li Y, Lemke K, Klena N, Liu X, Gabriel G, Tobita K, Jaspers M, Morgan LC, Shapiro AJ, Letteboer Stef JF, Mans DA, Carson JL et al.: DYXICI is required for axonemal dynein assembly and ciliary motility. Nature genetics 2013, 45:995-1003.

\section{FlOOOPrime \\ RECOMMENDED}

67. Merveille A, Davis EE, Becker-Heck A, Legendre M, Amirav I, Bataille G, Belmont J, Beydon N, Billen F, Clément A, Clercx C, Coste A,
Crosbie R, Blic J de, Deleuze S, Duquesnoy P, Escalier D, Escudier E, Fliegauf M, Horvath J, Hill K, Jorissen M, Just J, Kispert A, Lathrop M, Loges NT, Marthin JK, Momozawa Y, Montantin G, Nielsen KG et al.: CCDC39 is required for assembly of inner dynein arms and the dynein regulatory complex and for normal ciliary motility in humans and dogs. Nature genetics 201 I, 43:72-8.

\section{FlOOOPrime
RECOMMENDED}

68. Olbrich H, Häffner K, Kispert A, Völkel A, Volz A, Sasmaz G, Reinhardt $R$, Hennig $S$, Lehrach $H$, Konietzko $N$, Zariwala $M$, Noone PG, Knowles M, Mitchison HM, Meeks M, Chung Eddie MK, Hildebrandt F, Sudbrak R, Omran H: Mutations in DNAH5 cause primary ciliary dyskinesia and randomization of left-right asymmetry. Nature genetics 2002, 30:143-4.

\section{FlOOOPrime
RECOMMENDED}

69. Omran H, Häffner K, Völkel A, Kuehr J, Ketelsen UP, Ross UH, Konietzko N, Wienker T, Brandis M, Hildebrandt F: Homozygosity mapping of a gene locus for primary ciliary dyskinesia on chromosome $5 \mathrm{p}$ and identification of the heavy dynein chain DNAH5 as a candidate gene. American journal of respiratory cell and molecular biology 2000, 23:696-702.

70. Failly M, Bartoloni L, Letourneau A, Munoz A, Falconnet E, Rossier C, de Santi, MM, Santamaria F, Sacco O, DeLozier-Blanchet CD, Lazor R, Blouin J: Mutations in DNAH5 account for only 15\% of a nonpreselected cohort of patients with primary ciliary dyskinesia. Journal of medical genetics 2009, 46:28I-6.

7I. Zariwala MA, Leigh MW, Ceppa F, Kennedy MP, Noone PG, Carson JL, Hazucha MJ, Lori A, Horvath J, Olbrich H, Loges NT, Bridoux A, Pennarun G, Duriez B, Escudier E, Mitchison HM, Chodhari R, Chung, Eddie MK, Morgan LC, de longh, Robbert U, Rutland J, Pradal U, Omran $\mathrm{H}$, Amselem S, Knowles MR: Mutations of DNAII in primary ciliary dyskinesia: evidence of founder effect in a common mutation. American journal of respiratory and critical care medicine 2006, 174:858-66.

72. Failly M, Saitta A, Muñoz A, Falconnet E, Rossier C, Santamaria F, de Santi, Maria Margherita, Lazor R, Delozier-Blanchet CD, Bartoloni L, Blouin J: DNAII mutations explain only $2 \%$ of primary ciliary dykinesia. Respiration; international review of thoracic diseases 2008, 76:198-204.

73. Loges NT, Olbrich H, Fenske L, Mussaffi H, Horvath J, Fliegauf M, Kuhl H, Baktai G, Peterffy E, Chodhari R, Chung Eddie MK, Rutman A, O'Callaghan C, Blau H, Tiszlavicz L, Voelkel K, Witt M, Zietkiewicz E, Neesen J, Reinhardt R, Mitchison HM, Omran H: DNAI2 mutations cause primary ciliary dyskinesia with defects in the outer dynein arm. American journal of human genetics 2008, 83:547-58.

74. Mazor M, Alkrinawi S, Chalifa-Caspi V, Manor E, Sheffield VC, Aviram M, Parvari R: Primary ciliary dyskinesia caused by homozygous mutation in DNALI, encoding dynein light chain I. American journal of human genetics 20II, 88:599-607.

75. Horváth J, Fliegauf M, Olbrich H, Kispert A, King SM, Mitchison H, Zariwala MA, Knowles MR, Sudbrak R, Fekete G, Neesen J, Reinhardt R, Omran $\mathrm{H}$ : Identification and analysis of axonemal dynein light chain $\mathbf{I}$ in primary ciliary dyskinesia patients. American journal of respiratory cell and molecular biology 2005, 33:4I-7.

76. Hjeij R, Lindstrand A, Francis R, Zariwala MA, Liu X, Li Y, Damerla R, Dougherty GW, Abouhamed M, Olbrich H, Loges NT, Pennekamp P, Davis EE, Carvalho, Claudia MB, Pehlivan D, Werner C, Raidt J, Köhler G, Häffner K, Reyes-Mugica M, Lupski JR, Leigh MW, Rosenfeld M, Morgan LC, Knowles MR, Lo CW, Katsanis N, Omran H: ARMC4 mutations cause primary ciliary dyskinesia with randomization of left/right body asymmetry. American journal of human genetics 2013, 93:357-67.

77. Onoufriadis A, Shoemark A, Munye MM, James CT, Schmidts M, Patel M, Rosser EM, Bacchelli C, Beales PL, Scambler PJ, Hart SL, Danke-Roelse JE, Sloper JJ, Hull S, Hogg C, Emes RD, Pals G, Moore AT, Chung Eddie MK, Mitchison HM: Combined exome and wholegenome sequencing identifies mutations in ARMC4 as a cause of primary ciliary dyskinesia with defects in the outer dynein arm. Journal of medical genetics $2014,51: 61-7$. 
78. Onoufriadis A, Paff T, Antony D, Shoemark A, Micha D, Kuyt B, Schmidts M, Petridi S, Dankert-Roelse JE, Haarman EG, Daniels Johannes MA, Emes RD, Wilson R, Hogg C, Scambler PJ, Chung Eddie MK, Pals G, Mitchison HM: Splice-site mutations in the axonemal outer dynein arm docking complex gene CCDCII 4 cause primary ciliary dyskinesia. American journal of human genetics 2013, 92:88-98.

79. Knowles MR, Leigh MW, Ostrowski LE, Huang L, Carson JL, Hazucha MJ, Yin W, Berg JS, Davis SD, Dell SD, Ferkol TW, Rosenfeld M, Sagel SD, Milla CE, Olivier KN, Turner EH, Lewis AP, Bamshad MJ, Nickerson DA, Shendure J, Zariwala MA: Exome sequencing identifies mutations in CCDCII4 as a cause of primary ciliary dyskinesia. American journal of human genetics 2013 , 92:99-106.

80. Hjeij R, Onoufriadis A, Watson CM, Slagle CE, Klena NT, Dougherty GW, Kurkowiak M, Loges NT, Diggle CP, Morante Nicholas FC, Gabriel GC, Lemke KL, Li Y, Pennekamp P, Menchen T, Konert F, Marthin JK, Mans DA, Letteboer Stef JF, Werner C, Burgoyne T, Westermann C, Rutman A, Carr IM, O'Callaghan C, Moya E, Chung Eddie MK, Sheridan E, Nielsen KG, Roepman $\mathrm{R}$ et al.: CCDCI5I mutations cause primary ciliary dyskinesia by disruption of the outer dynein arm docking complex formation. American journal of human genetics 2014, 95:257-74.

81. Loges NT, Olbrich H, Becker-Heck A, Häffner K, Heer A, Reinhard C, Schmidts M, Kispert A, Zariwala MA, Leigh MW, Knowles MR, Zentgraf H, Seithe H, Nürnberg G, Nürnberg P, Reinhardt R, Omran H: Deletions and point mutations of LRRC50 cause primary ciliary dyskinesia due to dynein arm defects. American journal of human genetics 2009, 85:883-9.

82. van Rooijen E, Giles RH, Voest EE, van Rooijen C, Schulte-Merker S, van Eeden Freek J: LRRC50, a conserved ciliary protein implicated in polycystic kidney disease. Journal of the American Society of Nephrology: JASN 2008, 19: I | 28-38.

83. Duquesnoy P, Escudier E, Vincensini L, Freshour J, Bridoux A, Coste A, Deschildre A, Blic J de, Legendre M, Montantin G, Tenreiro H, Vojtek A, Loussert C, Clément A, Escalier D, Bastin P, Mitchell DR, Amselem S: Loss-of-function mutations in the human ortholog of Chlamydomonas reinhardtii ODA7 disrupt dynein arm assembly and cause primary ciliary dyskinesia. American journal of human genetics 2009, 85:890-6.

84. Kott E, Duquesnoy P, Copin B, Legendre M, Dastot-Le Moal F, Montantin G, Jeanson L, Tamalet A, Papon J, Siffroi J, Rives N, Mitchell V, Blic J de, Coste A, Clement A, Escalier D, Touré A, Escudier E, Amselem S: Loss-of-function mutations in LRRC6, a gene essential for proper axonemal assembly of inner and outer dynein arms, cause primary ciliary dyskinesia. American journal of human genetics 2012, 91:958-64.

85. Horani A, Druley TE, Zariwala MA, Patel AC, Levinson BT, Van Arendonk Laura G, Thornton KC, Giacalone JC, Albee AJ, Wilson KS, Turner EH, Nickerson DA, Shendure J, Bayly PV, Leigh MW, Knowles MR, Brody SL, Dutcher SK, Ferkol TW: Whole-exome capture and sequencing identifies HEATR2 mutation as a cause of primary ciliary dyskinesia. American journal of human genetics 2012, $91: 685-93$.

86. Zariwala MA, Gee HY, Kurkowiak M, Al-Mutairi DA, Leigh MW, Hurd TW, Hjeij R, Dell SD, Chaki M, Dougherty GW, Adan M, Spear PC, Esteve-Rudd J, Loges NT, Rosenfeld M, Diaz KA, Olbrich H, Wolf WE, Sheridan E, Batten Trevor FC, Halbritter J, Porath JD, KohI S, Lovric S, Hwang D, Pittman JE, Burns KA, Ferkol TW, Sagel SD, Olivier $\mathrm{KN}$ et al.: ZMYNDIO is mutated in primary ciliary dyskinesia and interacts with LRRC6. American journal of human genetics 2013, 93:336-45

87. Moore DJ, Onoufriadis A, Shoemark A, Simpson MA, zur Lage Petra I, de Castro Sandra C, Bartoloni L, Gallone G, Petridi S, Woollard WJ, Antony D, Schmidts M, Didonna T, Makrythanasis P, Bevillard J, Mongan NP, Djakow J, Pals G, Lucas JS, Marthin JK, Nielsen KG, Santoni F, Guipponi M, Hogg C, Antonarakis SE, Emes RD, Chung Eddie MK, Greene Nicholas DE, Blouin J, Jarman AP et al: Mutations in ZMYND I 0, a gene essential for proper axonemal assembly of inner and outer dynein arms in humans and flies, cause primary ciliary dyskinesia. American journal of human genetics 2013, 93:346-56

FIOOOPrime
RECOMMENDED

88. Austin-Tse C, Halbritter J, Zariwala MA, Gilberti RM, Gee HY, Hellman N, Pathak N, Liu Y, Panizzi JR, Patel-King RS, Tritschler D, Bower R, O'Toole E, Porath JD, Hurd TW, Chaki M, Diaz KA, Kohl S, Lovric S, Hwang D, Braun DA, Schueler M, Airik R, Otto EA, Leigh MW, Noone PG, Carson JL, Davis SD, Pittman JE, Ferkol TW et al:: Zebrafish Ciliopathy Screen Plus Human Mutational Analysis Identifies C2 I orf59 and CCDC65 Defects as Causing Primary Ciliary Dyskinesia. American journal of human genetics 2013, 93:672-86.

89. Knowles MR, Ostrowski LE, Loges NT, Hurd T, Leigh MW, Huang L, Wolf WE, Carson JL, Hazucha MJ, Yin W, Davis SD, Dell SD, Ferkol TW, Sagel SD, Olivier KN, Jahnke C, Olbrich H, Werner C, Raidt J, Wallmeier J, Pennekamp P, Dougherty GW, Hjeij R, Gee HY, Otto EA, Halbritter J, Chaki M, Diaz KA, Braun DA, Porath JD et al.: Mutations in SPAGI cause primary ciliary dyskinesia associated with defective outer and inner dynein arms. American journal of human genetics 2013, 93:7I I-20.

90. Becker-Heck A, Zohn IE, Okabe N, Pollock A, Lenhart KB, SullivanBrown J, McSheene J, Loges NT, Olbrich H, Haeffner K, Fliegauf M, Horvath J, Reinhardt R, Nielsen KG, Marthin JK, Baktai G, Anderson KV, Geisler R, Niswander L, Omran H, Burdine RD: The coiled-coil domain containing protein CCDC40 is essential for motile cilia function and left-right axis formation. Nature genetics 2011, 43:79-84.

\section{FlOOOPrime}

\section{RECOMMENDED}

91. Antony D, Becker-Heck A, Zariwala MA, Schmidts M, Onoufriadis A, Forouhan M, Wilson R, Taylor-Cox T, Dewar A, Jackson C, Goggin P, Loges NT, Olbrich H, Jaspers M, Jorissen M, Leigh MW, Wolf WE, Daniels, M Leigh Anne, Noone PG, Ferkol TW, Sagel SD, Rosenfeld M, Rutman A, Dixit A, O'Callaghan C, Lucas JS, Hogg C, Scambler PJ, Emes RD, Chung, Eddie MK et al.: Mutations in CCDC39 and CCDC40 are the major cause of primary ciliary dyskinesia with axonemal disorganization and absent inner dynein arms. Human mutation 2013, 34:462-72.

92. Blanchon S, Legendre M, Copin B, Duquesnoy P, Montantin G, Kott E, Dastot F, Jeanson L, Cachanado M, Rousseau A, Papon JF, Beydon N, Brouard J, Crestani B, Deschildre A, Désir J, Dollfus H, Leheup B, Tamalet A, Thumerelle C, Vojtek A, Escalier D, Coste A, Blic J de, Clément A, Escudier E, Amselem S: Delineation of CCDC39/ CCDC40 mutation spectrum and associated phenotypes in primary ciliary dyskinesia. Journal of medical genetics 2012, 49:410-6.

93. Carlén B, Lindberg S, Stenram U: Absence of nexin links as a possible cause of primary ciliary dyskinesia. Ultrastructural pathology 2003, 27:123-6.

94. Lindemann $C B$, Lesich KA: Flagellar and ciliary beating: the proven and the possible. Journal of cell science 2010, I23:519-28.

95. Castleman VH, Romio L, Chodhari R, Hirst RA, de Castro Sandra CP, Parker KA, Ybot-Gonzalez P, Emes RD, Wilson SW, Wallis C, Johnson CA, Herrera RJ, Rutman A, Dixon M, Shoemark A, Bush A, Hogg C, Gardiner RM, Reish O, Greene Nicholas DE, O'Callaghan C, Purton S, Chung Eddie MK, Mitchison HM: Mutations in radial spoke head protein genes RSPH9 and RSPH4A cause primary ciliary dyskinesia with central-microtubular-pair abnormalities. American journal of human genetics 2009, 84:197-209.

\section{FIOOOPrime
RECOMMENDED}

96. Olbrich H, Schmidts M, Werner C, Onoufriadis A, Loges NT, Raidt J, Banki NF, Shoemark A, Burgoyne T, Al Turki S, Hurles ME, Köhler G, Schroeder J, Nürnberg G, Nürnberg P, Chung Eddie MK, Reinhardt R, Marthin JK, Nielsen KG, Mitchison HM, Omran H: Recessive HYDIN mutations cause primary ciliary dyskinesia without 
randomization of left-right body asymmetry. American journal of human genetics 2012, 91:672-84.

\section{FlOOOPrime}

97. Schwabe GC, Hoffmann K, Loges NT, Birker D, Rossier C, de Santi Margherita $M$, Olbrich $H$, Fliegauf $M$, Failly $M$, Liebers $U$, Collura M, Gaedicke G, Mundlos S, Wahn U, Blouin J, Niggemann B, Omran H, Antonarakis SE, Bartoloni L: Primary ciliary dyskinesia associated with normal axoneme ultrastructure is caused by DNAHI I mutations. Human mutation 2008, 29:289-98.

\section{FlOOOPrime} RECOMMENDED

98. Fliegauf $M$, Olbrich $H$, Horvath J, Wildhaber $J H$, Zariwala MA, Kennedy M, Knowles MR, Omran H: Mislocalization of DNAH5 and DNAH9 in respiratory cells from patients with primary ciliary dyskinesia. American journal of respiratory and critical care medicine 2005, I 7 I: | 343-9.

\section{FlOOOPrime
RECOMMENDED}

99. Kispert A, Petry M, Olbrich H, Volz A, Ketelsen U, Horvath J, Melkaoui R, Omran H, Zariwala M, Noone PG, Knowles M: Genotype-phenotype correlations in PCD patients carrying DNAH5 mutations. Thorax 2003, 58:552-4.

100. Gherman A, Davis EE, Katsanis N: The ciliary proteome database: an integrated community resource for the genetic and functional dissection of cilia. Nature genetics 2006, 38:96I-2.

IOI. Davis EE, Katsanis N: The ciliopathies: a transitional model into systems biology of human genetic disease. Current opinion in genetics \& development 2012, 22:290-303

102. Badano JL, Mitsuma N, Beales PL, Katsanis N: The ciliopathies: an emerging class of human genetic disorders. Annual review of genomics and human genetics 2006, 7:125-48.

103. Horani A, Brody SL, Ferkol TW, Shoseyov D, Wasserman MG, Ta-shma A, Wilson KS, Bayly PV, Amirav I, Cohen-Cymberknoh M, Dutcher SK, Elpeleg O, Kerem E: CCDC65 mutation causes primary ciliary dyskinesia with normal ultrastructure and hyperkinetic cilia. PloS one 2013, 8:e72299.

104. Pennarun G, Chapelin C, Escudier E, Bridoux AM, Dastot F, Cacheux V, Goossens $M$, Amselem S, Duriez B: The human dynein intermediate chain 2 gene (DNAI2): cloning, mapping, expression pattern, and evaluation as a candidate for primary ciliary dyskinesia. Human genetics 2000, 107:642-9.

105. Alsaadi MM, Erzurumluoglu AM, Rodriguez S, Guthrie Philip Al, Gaunt TR, Omar HZ, Mubarak M, Alharbi KK, Al-Rikabi AC, Day lan NM: Nonsense mutation in coiled-coil domain containing I 5 I gene (CCDCI5I) causes primary ciliary dyskinesia. Human mutation 20|4, 35:|446-8

106. Horani A, Ferkol TW, Shoseyov D, Wasserman MG, Oren YS, Kerem B, Amirav I, Cohen-Cymberknoh M, Dutcher SK, Brody SL, Elpeleg O, Kerem E: LRRC6 mutation causes primary ciliary dyskinesia with dynein arm defects. PloS one 2013, 8:e59436.

107. Serluca FC, Xu B, Okabe N, Baker K, Lin S, Sullivan-Brown J, Konieczkowski DJ, Jaffe KM, Bradner JM, Fishman MC, Burdine RD: Mutations in zebrafish leucine-rich repeat-containing six-like affect cilia motility and result in pronephric cysts, but have variable effects on left-right patterning. Development (Cambridge, England) 2009, I36:|62I-3I.

108. Ferrante MI, Zullo A, Barra A, Bimonte S, Messaddeq N, Studer M, Dollé $P$, Franco $B$ : Oral-facial-digital type I protein is required for primary cilia formation and left-right axis specification. Nature genetics 2006, 38: I I 2-7.

FOOOPrime
RECOMMENDED

109. Romio L, Fry AM, Winyard, Paul JD, Malcolm S, Woolf AS, Feather SA: OFDI is a centrosomal/basal body protein expressed during mesenchymal-epithelial transition in human nephrogenesis. Journal of the American Society of Nephrology: JASN 2004, I 5:2556-68.

I10. Ghosh AK, Murga-Zamalloa CA, Chan L, Hitchcock PF, Swaroop A, Khanna $\mathrm{H}$ : Human retinopathy-associated ciliary protein retinitis pigmentosa GTPase regulator mediates cilia-dependent vertebrate development. Human molecular genetics 2010, 19:90-8.

I I I. Shu X, Zeng Z, Gautier P, Lennon A, Gakovic M, Patton EE, Wright AF: Zebrafish Rpgr is required for normal retinal development and plays a role in dynein-based retrograde transport processes. Human molecular genetics 2010, 19:657-70.

II2. Hong DH, Pawlyk BS, Shang J, Sandberg MA, Berson EL, Li T: A retinitis pigmentosa GTPase regulator (RPGR)-deficient mouse model for $\mathbf{X}$-linked retinitis pigmentosa (RP3). Proceedings of the National Academy of Sciences of the United States of America 2000, 97:3649-54.

II3. Zeiss CJ, Ray K, Acland GM, Aguirre GD: Mapping of X-linked progressive retinal atrophy (XLPRA), the canine homolog of retinitis pigmentosa 3 (RP3). Human molecular genetics 2000, 9:531-7.

I 14. Zhang Q, Acland GM, Wu WX, Johnson JL, Pearce-Kelling S, Tulloch B, Vervoort R, Wright AF, Aguirre GD: Different RPGR exon ORF I5 mutations in Canids provide insights into photoreceptor cell degeneration. Human molecular genetics 2002, I I:993-1003.

II5. Beltran WA, Hammond P, Acland GM, Aguirre GD: A frameshift mutation in RPGR exon ORFI5 causes photoreceptor degeneration and inner retina remodeling in a model of $\mathbf{X}$ linked retinitis pigmentosa. Investigative ophthalmology \& visual science 2006, 47: I669-8I.

I16. van Dorp DB, Wright AF, Carothers AD, Bleeker-Wagemakers EM: A family with RP3 type of X-linked retinitis pigmentosa: an association with ciliary abnormalities. Human genetics 1992 , 88:331-4.

I 17. Dry KL, Manson FD, Lennon A, Bergen AA, van Dorp DB, Wright AF: Identification of a $5^{\prime}$ splice site mutation in the RPGR gene in a family with X-linked retinitis pigmentosa (RP3). Human mutation 1999, | 3:|4|-5.

II8. Balestra FR, Gönczy P: Multiciliogenesis: multicilin directs transcriptional activation of centriole formation. Current biology: CB 2014, 24:R746-9.

I19. Ma L, Quigley I, Omran H, Kintner C: Multicilin drives centriole biogenesis via E2f proteins. Genes \& development 20 I4, 28: I 46 I-7I.

120. Stubbs JL, Vladar EK, Axelrod JD, Kintner C: Multicilin promotes centriole assembly and ciliogenesis during multiciliate cell differentiation. Nature cell biology 20I2, I4:|40-7.

\section{FlOOPrime}

\section{RECOMMENDED}

121. Watson CM, Crinnion LA, Morgan JE, Harrison SM, Diggle CP, Adlard J, Lindsay HA, Camm N, Charlton R, Sheridan E, Bonthron DT, Taylor GR, Carr IM: Robust diagnostic genetic testing using solution capture enrichment and a novel variant-filtering interface. Human mutation 2014, 35:434-4l. 